Available Online at https://journal.unismuh.ac.id/index.php/otoritas

Otoritas : Jurnal Ilmu Pemerintahan, 9 (1), April 2019, 12-27

\title{
Collaborating Local Government Agencies to Prevention Adolescent Reproductive Health in Makassar, Indonesia
}

\author{
Agus Heruanto Hadna ${ }^{1}$, Nasrulhaq ${ }^{2 *}$ \\ ${ }_{1}^{1}$ Department of Public Policy and Management, Faculty of Social and Political Sciences, \\ Universitas Gadjah Mada, Jl. Sosio Yustisia No. 1, Yogyakarta, 55281, Indonesia. \\ ${ }^{2}$ Department of Public Administration, Faculty of Social and Political Sciences, \\ Universitas Muhammadiyah Makassar, Jl. Sultan Alauddin No. 259, Makassar, 90221, Indonesia.
}

Received: 17 February 2019; Revised: 21 April 2019; Accepted: 26 April 2019

\begin{abstract}
Collaboration is an approach and concept of managing public policy in Makassar, Indonesia. Recently, the municipality of Makassar has capitalized on the collaboration of local government agencies regarding public affairs to prevent issues of Adolescent Reproductive Health (ARH). ARH is a strategic issue for local government so that it is solved collaboratively. The collaborating governmental organization comprises the Department of Education, Health, Family Planning, and all of the Urban Villages. This research employed a qualitative method focusing on the analysis of collaborative phenomena of local government agencies in Generation Planning Program through Adolescent Counseling Information Center (ACIC) and Adolescent Families Development (AFD) in Makassar. Data were obtained and analyzed in an orderly and structured manner with general qualitative approach. Based on the field research, the local government agencies collaborate in two ways. The first collaboration deals with the sectoral term which is the involvement of the government agencies related to adolescent reproductive health policy. The second collaboration deals with the regional term including the involvement of the Sub-District and Urban Villages in Makassar as grassroots bureaucracy. Collaborative themes and relations are the main findings in this article. An interesting theme in the idea of collaboration is mutual interdependence, while an exciting theme in the implementation of collaborative action is joint interaction. Organizational relationships in collaboration between local government agencies are coordination, consolidation, consultation, and command. This study concluded that sectoral and regional collaboration is proper in bringing a solution to public health affairs that are very complex.
\end{abstract}

Keywords: Collaboration; Local Government; Adolescent Reproductive Health

How to Cite: Hadna, A. H., \& Nasrulhaq, N. (2019). Collaborating Local Government Agencies to Prevention Adolescent Reproductive Health in Makassar, Indonesia. Otoritas : Jurnal Ilmu Pemerintahan, 9(1), 12-27.

Permalink/DOI: https://doi.org/10.26618/ojip.v9i1.2025

*)Corresponding Author.

E-Mail : nasrulhaq@unismuh.ac.id

Copyright (C) 2019, Otoritas : Jurnal Ilmu Pemerintahan, ISSN: 2088-3706 (Print), ISSN: 2502-9320 (Online) 
Available Online at https://journal.unismuh.ac.id/index.php/otoritas

Otoritas : Jurnal Ilmu Pemerintahan, 9 (1), April 2019, 13

\section{INTRODUCTION}

Local governments have frequently worked collaboratively in dealing with various health problems in Indonesia, one of which is an Adolescent Reproductive Health (ARH) issue in Makassar City in particulars. ARH is one of a national problem that its authority is decentralized to the local government. The rules based on the Law of the Republic of Indonesia Number 23 of 2014 on Local Government. The municipality of Makassar is considered actively engaged in adolescence people's activities using a collaborative approach. One of the general policies outlined in the document of the MediumTerm Development Plan of the municipality of Makassar for 2014-2019 is the service of ARH. The Family Planning Department is designated responsible for the program. To carry it out, Family Planning Department of the municipality of Makassar collaborates with the Education Department and the Health Department sectorally and collaborate with the SubDistricts and Urban villages of Makassar across regions.

Collaborating local government agencies is continually carried out from year to year because each governmental agency involved has a role and task determined by the municipality of Makassar. The multi-actor government involved in addressing a variety of things about to ARH contributes to the increasing conduct of studies on current issues of public administration. Collaborative action is a critical case currently in many countries. Many kinds of literature have been discussing its phenomenon. According to the Ottawa Charter for Health Promotion in 1986, there is a great need for 'intersectoral' collaboration in public health (Axelsson \& Axelsson, 2006). Some encouraging evidence from programmes, projects, and studies suggests that intersectoral collaboration is feasible and useful (Adeleye \& Ofili, 2010). Inter- organizational collaboration has been described as a means as well as an end in the literature of public health, it is organized in different ways depending mainly on the degree of integration required (Axelsson \& Axelsson, 2006).

Generally, the meaning of intersectoral collaboration in this study refers to the definition proposed by the World Health Organization (WHO) because the ARH is a part of the health problem. The definition of intersectoral was put forward in the International Conference on Intersectoral Action for Health 1997. WHO said that a recognised relationship between part or parts of the health sector with part or parts of another sector which has been formed to take action on an issue to achieve health outcomes (or intermediate health outcomes) in a way that is more effective, efficient or sustainable than could be achieved by the health sector acting alone (www.who.int). Specifically, intersectoral collaboration (ISC) is defined as collaboration between health and non-health local government officials and is a prerequisite for the development of integrated policies that address wicked public health problems (A. M. Hendriks et al., 2015).

A phenomenon in ARH issues is of interest to be examined regarding public administration and public policy. Collaboration is a salient topic in the public administration and management literature and for a good reason (Smith, 2009). This issue has developed into a public issue in various countries, including Indonesia. The Laws of the Republic of Indonesia Number 36 of 2009 concerning the health says that the government must ensure the availability of information facilities and safe, affordable and quality reproductive health service facilities. Studies on ARH issues continue to evolve and receive earnest attention. The National Family Planning and Population Board (NFPPB) in partnership with United States Agency for International Development (USAID) for 
Indonesia continues to carry out Demographic and Health Surveys periodically to glean information on key indicators of ARH such as sexual experience, knowledge of Human Immunodeficiency Virus and Acquired Immune Deficiency Syndrome (HIV-AIDS) and use of illegal drugs.

According to Mitchell \& Pattison (2012), intersectoral collaboration plays an essential part in the provision of social and health services. Interorganizational collaboration is intended to resolve any unsolved problems which an organization seeks to solve on its own (Savage, Bunn, Gray, Xiao, \& Wang, 2010). The collaborative approach is considered instrumental in addressing public health issues. However, to carry out intersectoral collaboration requires a more collaborative organizational structure (F. Hendriks, 2014). Effective collaboration may be hard to attain due to the hindrances of internal actors such as differences of opinion, institutional constraints and lousy leadership (Liu \& Zheng, 2014). Spiegel et al., (2012), the process of cross-sectoral action is liable for the health process.

The emerging cross-sectoral initiative is intended to address the same health services and recognize the role of social determinants controlled by the government (McQueen, 2013). The intersectoral challenges arise from the collaboration, organizational and bureaucratic issues, the balance between process and content (Freudenberg, 2008). McQueen, (2013) argued that the key to success of inter-sectoral action comprises political will, the interests of citizens and partners, the political interests of the health sector, proximity problems, leadership, situational context, resources, and practical implementation. Moreover, Bao, Bhalla, \& Bennett (2015), intersectoral action requires greater collaboration and a common understanding of the relevance of the sectors involved. Points of intervention to develop greater collaboration and poten- tially improve program effectiveness (Burgess et al., 2016).

The collaboration of local government agencies to prevention adolescent reproductive health is one of the phenomena in public health as section affairs of local government. The researcher focuses on local government agencies that make collaboration because collaborative themes and relationship have characteristic for studying. The local government does collaborative action in Generation Planning Program through Adolescent Counseling Information Center (ACIC) and Adolescent Families Development (AFD).

Themes in collaboration develop the principles of the collaborative advantage and collaborative inertia (see Osborne, 2010). Osborne (2010) uses the term 'theme' to describe issues that tend to energize. Moreover, this article is attempting an additional reconstruction based on published research on interorganizational integration and collaboration in public health and related welfare services (see Axelsson \& Axelsson, 2006). Research that studies and develop a collaborative relationship is still less.

The present study aims to answer two research questions based on phenomena and literature reviews. The first, what are the views of public officials on the active collaborative themes of local governments agencies starting from the initial stages of the program and continuing through the stages of implementation?.

The second, how is the collaborative relationship between local governments agencies in Generation Planning Program through Adolescent Counseling Information Center (ACIC) and Adolescent Families Development (AFD) in Makassar?. The results of the study can contribute to the development of collaborative studies, especially the scope of local government agencies. Complex problems such as ARH need to be studied with vari- 
Available Online at https://journal.unismuh.ac.id/index.php/otoritas

Otoritas : Jurnal Ilmu Pemerintahan, 9 (1), April 2019, 15

ous approaches based on research results to maximize the achievement of policy or program for public health.

\section{RESEARCH METHODS}

The study was conducted using a qualitative approach to case studies. The analysis unit is Generation Planning Program through Adolescent Counseling Information Center (ACIC) and Adolescent Families Development (AFD) in Makassar. Data were obtained by doing three techniques. The first, in-depth interview was done with ten key informants from representatives of a local government organization that carry out collaborative actions. These key informants are two people from the Department of Family Planning, two people from Department of Education, two people from Department of Health, three people from Sub-district and three people from Urban Village. Researchers also conducted in-depth interviews with several ACIS and AFD managers in Makassar city. Data were analyzed descriptively based on recording and transcription. The seconds, related documents were used as a data source for the triangulation process such as the Planning Document of Makassar city government 2014 - 2019, the Central and Local Government Regulations on ARH from 2011 to 2017 and Report of Demographic and Health Surveys 2017. Data were collected manually and online from the website. The researcher compared all document in detail. The third, observations to eleven ACIC and eleven AFD groups as program targets were also conducted to strengthen research findings. The observed location is those that are in the active and inactive categories to compare the performance and impact of collaboration. The result of the field observation meant to triangulate all of the data. All of the data were analyzed (validity and reliability) step by step based on a qualitative research approach (Creswell, 2014).

\section{RESULTS AND DISCUSSION}

\section{Overview of Adolescent Reproductive Health}

Adolescent Reproductive Health $(\mathrm{ARH})$ is a healthy condition concerning adolescents' reproductive system, function, and process. Being healthy in this respect does not mean being free from illness or disability, but it also refers to mental and social health. In bringing a solution to a wide range of relevant problems in Indonesia, the central government through NFPPB pays close attention to the adolescent reproductive health problems. The ARH Program is a follow-up to the policy direction and national strategy in NFPPB outlined in 'Book I of National Medium- Term Development Plan 20152019'. The policies comprise adolescent's improved knowledge and understanding of reproductive health through education, socialization on the importance of 12 year compulsory education in the context of maturation of marriage age, and increased family planning services for young couples to prevent teen birth.

The central government devolves the implementation of activities on young people's resilience issues to the regional government based on the Law of the Republic of Indonesia Number 23 of 2014 concerning Regional Government. Collaboration activities of other departments were mostly supportive, such as providing venues, recruiting participants and publicizing, and other administrative supports (Kang, 2016). The task division of the central and regional governments can see table 1 .

In general, the issues of Adolescent Reproductive Health in Indonesia are exciting. The results of Demographic and Health Surveys 2017 conducted by the National Population and Family Planning Board in collaboration with USAID for Indonesia reach some conclusions. The first, the prevalence of smoking, alcohol consumption, and drug abuse increases as 
young men age. The percentage of men smoking and drinking alcohol in urban areas is lower than in rural areas. The percentage of men's drug abuse in urban areas is high. The second, percentage of unmarried women and men aged 20-24 years and living in urban areas who have heard about HIV-AIDS is higher than other groups. In general, the level of knowledge about HIV-AIDS increases with the education level of men and women. The third, percentage of adolescent males and females in the age group 20-24 years, living in urban areas, and earning a high education and knowing how to prevent HIV-AIDS by limiting sexual intercourse is higher than those in other groups. The fourth, percentage of adolescent males who agree on premarital sexual relations is higher than female adolescents. Young women and men tend to say that men may have sexual intercourse before marriage. With young men, eight percent of adolescents agree that men have sex before marriage, and four percent agree if women do it. The fifth, the percentage of adolescent males aged 20-24 who claimed to have had sexual intercourse are higher than that of adolescent males in the age group of the 15-19. Ten percent of unmarried women who have no education have had sex which is higher than those who have completed primary and higher education.

Based on the data of Demographic and Health Surveys 2017, the government of Makassar city seeks to make continued and efforts by establishing Adolescent Counseling Information Center (ACIC) and Adolescent Families Development (AFD) which accommodates the implementation and management of programs that the goals can be more quickly and precisely attained. The ACIC is an activity center intended to prepare young people for marriage life managed from, by and for adolescents in order to provide information and counseling services on family life planning catered to adolescents and other supporting activities. AFD consists

Table 1. Task Distribution Concerning the Adolescent Reproductive Health Source: Elaborated by the authors from the Law of the Republic of Indonesia Number 23 of 2014 on Local Government (2018)

\begin{tabular}{|c|c|c|c|}
\hline Program & Central Government & $\begin{array}{l}\text { Local government } \\
\text { (Province) }\end{array}$ & $\begin{array}{c}\text { Local Government } \\
\text { (Regency/ Munici- } \\
\text { pality) }\end{array}$ \\
\hline $\begin{array}{l}\text { Adolescent } \\
\text { Reproductive } \\
\text { Health }\end{array}$ & $\begin{array}{l}\text { Program design devel- } \\
\text { opment } \\
\text { Supervision over local } \\
\text { (provincial) govern- } \\
\text { ment performance } \\
\text { Increasing the partici- } \\
\text { pation of relevant } \\
\text { institutions at the } \\
\text { national level } \\
\text { Empowering the rele- } \\
\text { vant societal organi- } \\
\text { zations at the na- } \\
\text { tional level }\end{array}$ & $\begin{array}{l}\text { Management of pro- } \\
\text { gram implementa- } \\
\text { tion } \\
\text { Supervision over local } \\
\text { government perfor- } \\
\text { mance (regency/ } \\
\text { municipality) } \\
\text { Increasing the partici- } \\
\text { pation of relevant } \\
\text { institutions at the } \\
\text { provincial level } \\
\text { Empowering relevant } \\
\text { societal organiza- } \\
\text { tions at the provin- } \\
\text { cial level }\end{array}$ & $\begin{array}{l}\text { Program implementa- } \\
\text { tion } \\
\text { Indicator-based per- } \\
\text { formance assess- } \\
\text { ment } \\
\text { Increasing the partici- } \\
\text { pation of relevant } \\
\text { institutions } \\
\text { (regency/ munici- } \\
\text { pality) } \\
\text { Empowering relevant } \\
\text { societal organiza- } \\
\text { tions at Regency } \\
\text { and Municipality } \\
\text { level }\end{array}$ \\
\hline
\end{tabular}


of families who have adolescents aged 1024 years. AFD aims to enhance the knowledge and skills of parents and other family members in the care and nurture of adolescents to bring about high participation, coaching, and independence for group members. The establishment of the two entities is a part of the annual target to be continuously improved for the realization of performance indicators for adolescent resilience in Makassar.

For the ACIC, the management is conducted by Junior High Schools and the equivalent level of educational unit and Senior High Schools and another equivalent level of the educational unit. In the government of Makassar city, the ACID is actively operational at Senior High School and Junior High School level. The Principal legitimizes the Management of ACID. Meanwhile, the AFD is conducted at the neighborhood units whose management is legitimized by the head of the Urban Village. The ACIC and AFD are formed out of the collaboration between the Family Planning Department, the Education Department, the Health Department, Subdistricts and Urban Villages in the government of Makassar City. Currently, there are 77 ACIC in several schools and 286 AFD in all Urban Villages in Makassar municipality.

The implementation of activities pertinent to ARH involves various local organizations in Makassar municipality as the apparatus including three sectoral departments (family planning, education, and health), 15 sub-districts, and 153 urban villages. The sectoral department is an apparatus to carry out the government affairs which come under the authority of the local government. The sub-district is a regional apparatus territorial which is formed for the improved coordination of government administration, public services, and empowerment of urban communities. The urban village is a region of the apparatus of a sub-district established to assist or carry out some of the sub- districts tasks. The involvement of a variety of local organizations is due to existing standard functions in solving adolescent problems that have been regulated by the municipality of Makassar particularly adolescent reproductive health.

\section{Sector-Based Collaboration}

The local government agencies referred to in the sectoral collaboration comprise the Family Planning Department, the Education Department, and the Health Department. Sectoral collaboration can be called horizontal integration (Axelsson \& Axelsson, 2006). The Family Planning Department acts as the responsible one or leading sector. In practice, the three local government organizations collaborate to attain the maximum possible results. It is involved involvement in the ARH Program because of the linkage between roles and tasks in public services prescribed in the Regional Regulation of Makassar Number 8 of 2016 concerning the Formation and Organization of Local Government. The main reason for the collaboration of each regional apparatus organization is: (1) the Family Planning Department engages in collaboration because of the difficulty to perform its roles and tasks in addressing issues about population, family planning and family welfare on their own. The Adolescent Reproductive Health Program is one of the critical activities of the municipality of Makassar whose responsibility is delegated to the Family Planning Department; (2) the Education Departement seek collaboration because the ARH Program is aimed at the Senior High School and Junior High School students for educational purpose. The Education department receives excellent help from the program that enables it to succeed in the teaching and learning process in the classroom and outside the classroom; (3) the Health Department collaborates on account of activities related to ARH concerning public health issues, especially adolescents. The program helps 
the health department in controlling the health of adolescents to avoid unwanted risks.

The Family Planning Department is not capable of carrying out the activities of the ARH Program to the best advantage without collaborating with the Education Department and the Health Department. Existing rules stress that if local government organizations intend to carry out activities in schools, they are obliged to request recommendations from the Education Departement. Hence, all activities to be carried out by the Family Planning Department in schools requires approval from the Education Department. The Education Department has a vested authority to control the governance of school both physically and non-physically. The Health Department has a strategic role and duties because the Family Planning Department has limited resources. Implementing ARH entails human resources such as doctors and nurses and adequate facilities such as medical tools. Operationally, the Health Department takes part through Community Health Center (CHC) located in all Sub-districts in the municipality of Makassar. The CHC is a health service unit established by the Education Department to render public health services easily accessible in their respective regions.

The role of each local government organization in the municipality of the Makassar in conducting the ARH Program is as follows table 2 .

The ACIC serving as a 'container' of the ARH Program that is established by the Family Planning Department in various schools is entrusted to conduct activities in their respective immediate groups. Activities are aimed to deepen and reinforce understanding including 1) increasingly eight functions of family, 2) maturing marriage age, 3) sexuality, 4) narcotics, alcohol, and psychotropic drugs, 5) HIV-AIDS, 6) life skills education, 7) advocacy skill, communicative, informing and educating skill, 8) material development as needed. Collaboration carried out by local government organizations in Makassar leads to a 'container' whose quantity and quality is expected to maximize the attainment of performance indicators.

Table 2. The Role of Local Government Department in Makassar, Indonesia

Source: Processed by the authors (2018)

\begin{tabular}{|c|c|c|}
\hline Family Planning Department & Education Department & Health Department \\
\hline $\begin{array}{l}\text { Forming the management of } \\
\text { Youth Counseling Information } \\
\text { Center }\end{array}$ & Endorsing an activity & $\begin{array}{l}\text { Facilitate the use of } \\
\text { medical tools }\end{array}$ \\
\hline $\begin{array}{l}\text { Conducting capacity building } \\
\text { of the management of Youth } \\
\text { Counseling Information Center }\end{array}$ & $\begin{array}{l}\text { Taking a log of the program } \\
\text { target school }\end{array}$ & $\begin{array}{l}\text { Conducting a reproduc- } \\
\text { tive health check-up }\end{array}$ \\
\hline $\begin{array}{l}\text { Performing overseeing pro- } \\
\text { gram }\end{array}$ & $\begin{array}{l}\text { Guiding the management of } \\
\text { Youth Counseling Infor- } \\
\text { mation Center }\end{array}$ & $\begin{array}{l}\text { Conducting health } \\
\text { counseling for adoles- } \\
\text { cents }\end{array}$ \\
\hline $\begin{array}{l}\text { Conducting socializing pro- } \\
\text { gram }\end{array}$ & $\begin{array}{l}\text { Conducting socializing pro- } \\
\text { gram }\end{array}$ & $\begin{array}{l}\text { Conducting socializing } \\
\text { program }\end{array}$ \\
\hline $\begin{array}{l}\text { Extending material and non- } \\
\text { material aid }\end{array}$ & $\begin{array}{l}\text { Extending material and non- } \\
\text { material aid }\end{array}$ & $\begin{array}{l}\text { Extending material and } \\
\text { non-material aid }\end{array}$ \\
\hline
\end{tabular}


The ACIC exists as a formal and legal entity which is consistently supported by local government regulations and relevant regional apparatus organizations. The sectoral collaboration model is displayed as follows the figure 1 .

\section{Region-Based Collaboration}

ARH activities are conducted throughout the Urban Villages in Makassar based on the existing neighborhood units. There are 15 Sub-districts involved in providing ARH activities, and $153 \mathrm{Ur}-$ ban Villages which carry out the activities at the neighborhood level. One Subdistrict comprises several Urban Villages. One Urban Villages consists are several neighborhood units. The main reason for the active involvement of Sub-districts and Urban Villages is that families with adolescents are the target of ARH activity. Regional collaboration can be called vertical integration (Axelsson \& Axelsson, 2006). The responsibility for the wellbeing and health of the community rests with the Urban Villages as it directly interacts with the surrounding residents and knows well about the complexity of whatever has happened. In order to streamline the implementation, assessment, and supervision, a "vehicle" is established to achieve indicators more easily. The Family Planning Department collaborates with the Sub-districts and Urban Villages. The collaboration is proved by the selection of Family Planning Department in each Sub-district and Urban Villages who serve to socialize programs.

Family planning service providers are civil servants granted duties, responsibilities, authority, and rights by the authorized official to extend counseling service, evaluation, and development activities regarding national population and family planning. The Family Planning Department comprises civil servants or noncivil servants appointed by authorized officials and granted duties, responsibilities to conduct activities on counseling service, evaluation, and development of family planning. The placement of the actors is done by the regional principle to augment the achievement of the indicators of the ARH Program. In carrying out the tasks, coordination needs to be made with the Urban Village. All activities to be carried out are reported to the Head of Urban Villages as a local government offi-

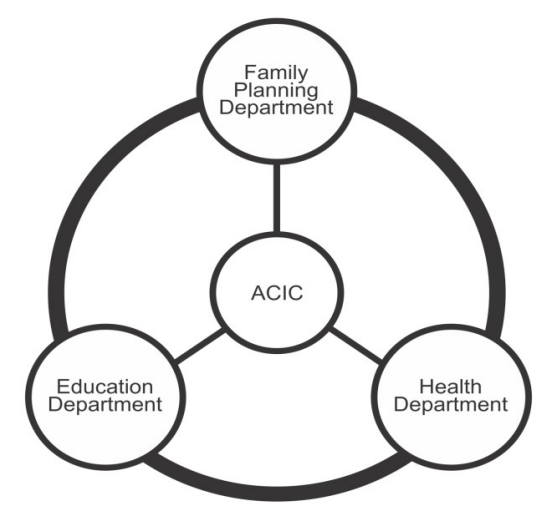

Figure 1. Sector-based Collaboration

Source: Analyzed by the authors (2018) 
Available Online at https://journal.unismuh.ac.id/index.php/otoritas

Otoritas : Jurnal Ilmu Pemerintahan, 9 (1), April 2019, 20

cial. Subsequently, the Head of the Urban Village passes the report on to the head of sub-district. They have full responsibility for all activities at the neighborhood level or community unit level. The Family Planning Department is assisted by family planning cadets from residents to make activities more effective.

A forum created to accommodate the activities of ARH for families with adolescents is called AFD. In Makassar, there is at least one AFD in the neighborhood unit or community unit. The head of Urban Villages together with family planning members is obliged to form a group for the management of ARH activities. One group of AFD consists of 10-30 families who have adolescents aged 10-24 years. The participation of the family is granted after meeting with the requirements. The materials discussed in the group include instilling moral values through eight functions of family, maturing the marriage age, sexuality, drugs, HIV-AIDS, life skills, gender-oriented family resilience and the fulfillment of adolescent nutrition. The material is delivered by Family Planning Department and cadets from the locality who have been trained to speak.
The existing program support for adolescent families results from collaboration between the Family Planning Department and Sub-districts as well as Urban Villages. The Education Department is not a part of this collaboration because it does not have roles and duties. The same is true with the Health Department because Family Planning Department providers and on the field actors are skilled ones and trained for ARH. If something related to the use of health facilities comes up, the officer may refer one to be examined at the CHC. The sectoral collaboration model is displayed in the figure 2 .

\section{Inter-Organizational Collaboration}

Inter-organizational collaboration in the government of Makassar city presents themes that attract attention to be studied. Specific themes strengthened because of the characteristics of the relationship between the organizations involved and also the issues resolved together. An interesting theme in the idea of collaboration is mutual interdependence, while an exciting theme in the implementation of collaborative action is joint interaction. Discussing the idea and implementation

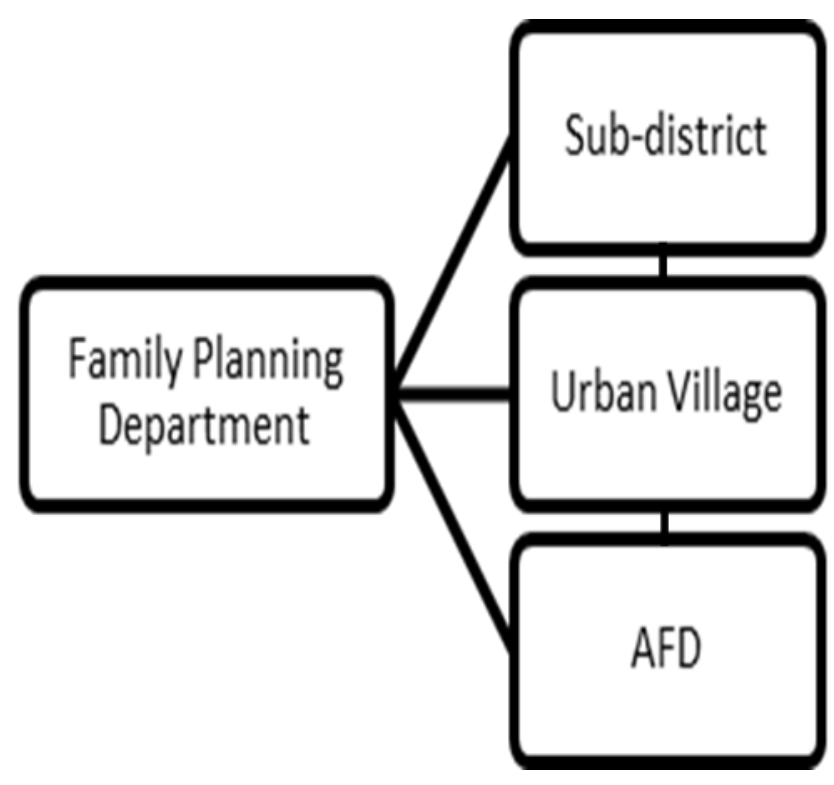

Figure 2. Region-based Collaboration

Source: Analyzed by the authors (2018) 
of collaboration are essential. According to Larsen, Koudenburg, Gulis, \& Rantala (2014), It is seen as very important that the collaboration itself should be addressed in an intersectoral manner starting from the initial stages of policy development and continuing through the stages of implementation and evaluation. Interorganizational collaboration makes possible information exchange, advice giving and pooling of resources for successful implementation (Palinkas et al., 2014). Moreover, collaboration requires supportive perceptions, intentions, and actions (Pucher, Candel, Krumeich, Boot, \& De Vries, 2015). Tooher et al., (2017) elucidated that the focus of the study in collaboration is on process networks and sectoral agenda alignment.

First, the theme is mutual interdependence. Based on Savage et al., (2010), the focus of the collaboration is the relationship in the form of interdependence. Collaboration between local government agencies begins with efforts to need each other between government organizations. The similarity of the target of the activity or program is the initial motivation to make a collective agreement. The similarity of activity objectives triggers mutual dependence. By the effectiveness of the organizational function, the agencies related to collaborative action remain guided by the achievement of the Makassar City Government's strategic plan. The Makassar City Government gives freedom to each local government organization to do creativity so that the policies written in the planning documents can be appropriately implemented. In the end, the organizations involved feel helped in the implementation of their duties and responsibilities. Every problem faced is more accessible to solve with regulatory support and collaborative discredit. In a collaboration between regional apparatus organizations, the division of tasks and responsibilities is always prioritized so as not to overlap authority. The factor that makes collaboration not accomplished is because of the takeover of authority without approval or recommendations from the relevant organization. Intensity whose tasks and functions are taken over usually protests to other agencies. As a result, the organization does not compromise to collaborate. The interdependence of roles and functions unites the understanding of each agency.

Collaboration between local government organizations has a positive impact on the availability of resources in program implementation and the resolution of youth problems. The division of resources becomes the determinant of the formation of mutual interdependence. According to Palinkas et al., (2014), collaboration allows the pooling of resources. The allocation of sufficient resources influences collaboration (Larsen et al., 2014). The highest priorities in order to achieve intersectoral collaboration were sufficient resources, knowledge and expertise (Kang, 2016). The advantages of other agencies assist the weakness of one of the agencies. There is a proper distribution of resources; problems can be solved well too. The resources in question include human resources and facilities resources. The Family Planning Office controls resources related to adolescent resilience. The Education Office provides resources related to education. For the Health Service, its role and duties provide matters related to health. Likewise, with the sub-districts and urban village, both prepare the needs by their duties and responsibilities as stipulated in the existing provisions. Resources are always available when needed. Approval on the distribution of resources and the provision of facilities is carried out without the formalities of Memorandum of Understanding documents between regional apparatus organizations. The collaboration based on mutual awareness regarding their respective duties and responsibilities. 
The strength of the issue is also a determinant of mutual interdependence. If its problem is strategic, each of the relevant regional apparatus organizations is sure to have serious attention. Especially issues that cannot be solved individually. Adolescent Reproductive Health (ARH) issues concerning aspects of population control, education and health so that relevant agencies participate actively. The issue becomes strong because of the same interests (McQueen, 2013). Because the target is teenagers and families who have adolescents aged 10-24 years, SubDistricts and Urban Villages are also involved as responsible for the orderliness of its citizens. The Makassar City Government through the Mayor and Deputy Mayor only supervises and evaluates the performance of each local device organization. Local social and political conditions support the strength of the issue. Local government leadership is very influential in placing strategic or non-strategic issues. A substantial issue gets an adequate allocation of funds from the local government. Also, tough issues at the national level signal to local governments to resolve them at the local level through a program decentralization approach.

Second, the theme is joint interaction. This second theme points to aspects of the process of implementing the ARH program. Joint interaction only takes place when activities or programs are being carried out, and vice versa. Thus, the actions taken are periodic. The schedule of activities is uncertain, so interactions are not routine. If the activities carried out using a top-down approach, the organization of the local organization in advance so that the implementation of activities is more effective and efficient. Communication is the essential part of the joint action (Tooher et al., 2017). Communication is carried out non-formally and controlled by the Family Planning Department as a leading sector. Each local government agencies has individual employ- ees to communicate with each other. After communicating, activities or the program is implemented on the target object, on the contrary, activities initiated by the ACIC or AFD group with a buttom-up approach. There is no active communication between government organizations. The active party is only the ACIC or AFD group. The local government organizations are only involved in the participatory form. The agencies of Makassar government is involved when it is invited by the ACIC group or visited by the group to ask for help by their needs. This condition is called mutual interaction. There is an interaction between all parties involved. Although the activity of ACIC and AFD are independent, all activities remain coordinated to the Family Planning Department as the primary person in charge of the program.

The main factor determining the success or not succeeding joint interaction is commitment. Commitment is needed in every action of ARH because it is a determining factor in collaboration according to Osborne (2010). Furthermore, Larsen et al., (2014) said that commitment from all stakeholders influences the implementation and success of intersectoral health policies. Dealing with teenage problems is carried out in the long term so that seriousness is always maintained. In the implementation of the program, commitment of regional-based organization is very diverse. There are firm commitments, some are strong, and some are not strong. The number of Sub-districts and Urban Villages in the city of Makassar is a separate record. Some Urban Village is not well committed to activities held in their area. Lousy commitment is judged by the quality and quantity of active participation and the activeness of the formation of a forum for ARH target groups. Sub-districts that are less active see that the issue of ARH is the focus of sectoral organizational work. The leadership of the Urban Village Head is sometimes 
weak, so efforts to advocate for the community are also weak. Especially for service, all have an ethical commitment. Fieldwork performance of the Family Planning Department continues to increase. Services at the CHC are open every working day to receive visits from adolescents who are part of the action of ARH. The Health Department also always advises all schools under its control to make ACIC as one of the student activity units.

The next factor is trust. Trust is needed for stronger collaboration (Burgess et al., 2016). Smith concedes trust is an important component to understanding these relationships (2009). Trust is divided into the internal trust of the organizing institution and the public trust of the target program. Internal trust is strong. The accountability of each institution strengthens this trust. Specific Subdistricts and Urban Villages that have good public trust have had a direct impact on the quality of collaboration in regional organizations in achieving the target of the ARH. A very active AFD group also stimulates the Department, Sub-district, and Urban Village to continue to actively pay attention to teenagers and families who have teenagers aged 10-24 years. There is active feedback between the parties that interact. Indicator targets are achieved by planning if the implementers and targets interact actively. Likewise, with ACIC, schools that actively form ACIC and carry out activities also encourage local organizations to continue to pay more attention than those who are not active. The trust of the target object for the program carried out by the government actively supports collaborative actions of government, sectoral and regional organizations. Trust gives birth to interactions. Local government organizations, both sectoral and regional, lack activities in target groups that are not active. Collaborative action makes the interaction of all parties involved if the target group also takes action. Target group action is formed if the public trust is an active target group. The task of the government is to instill good public trust in order to create mutual interaction.

In summary, mutually interdependence and joint interaction are summarized into organizational relationships in collaboration between local government agencies. In order to sort out the relationships between the different forms of integration and collaboration, a distinction can be made between two main dimensions, vertical and horizontal integration (Axelsson \& Axelsson, 2006). In general, there are four classification relationships. The classification relationships are made sectoral and regional term. Sectoral term supports horizontal collaboration, and regional term supports vertical collaboration. The following is the description in the figure 3.

\begin{tabular}{|c|c|c|}
\hline Relation & Sectoral & Regional \\
\hline Sectoral & Coordination & Consolidation \\
\hline Regional & Consultation & Command \\
\hline
\end{tabular}

Figure 3. Collaborative Relation Source: Analyzed by the authors (2018) 
Coordination is the matter of regulating an organization or activity so that the rules and actions to be carried out are not contradictory. Coordination occurs when the sectoral, and regional apparatus organization has a working relationship with other sectoral organizations. For example, the Family Planning Department coordinates with the health service or the Education Department in coordination with the Health Department. In brief, coordination is done if the organizational level is horizontal with horizontal. Coordination within the government is called horizontal-internal coordination (see Hellevik, 2012).

Consolidation is an effort to strengthen or strengthen activities carried out together in order to succeed well. Consolidation occurs when the sectoral, and regional apparatus organization has a working relationship with regional equipment organizations. For example, the Family Planning Department consolidates with the Sub-district or Urban Village. In brief, consolidation is done if the organizational level is horizontal with vertical. Many local governments also are exploring new governance structures that involve combining operations or even consolidating units of government to maintain core services (Jimenez \& Hendrick, 2010). City officials have claimed that consolidation helped them improve efficiency (Wilson \& Grammich, 2017).

Consultation is the exchange of program ideas and ideas to get the best conclusions. Consultation occurs when the regional organization of the local government agencies conducts working relations with the sectoral organization. For example, Urban Villages consultation with the Health Department or Sub-district consultation with the Education Department. In brief, consultation is done if the organizational level is vertical with horizontal. According to Chalmers (2014), some countries show a growing use of consultations at all levels of government and consulta- tions might bring these benefits to the policy process.

Command is an order to carry out activities to be more organized in achieving targets. Commands occur if the regional organization of the local government has a working relationship with other regional organizations. For example, the Sub-district has a working relationship with the Urban Villages. The command work relationship only applies to the same area. There is no working relationship between Sub-district with Subdistrict and Urban Village with Urban Village. In brief, the command is done if the organizational level is top vertical with low vertical. Various project members found it hard to part with the power stance of command and control (Baarle, 2019).

\section{CONCLUSION}

Collaboration between local government agencies is essential to be done in solving the problems of ARH. This problem is part of local, national and international issues. The position of the issue is strategic and complicated, so it requires the involvement of various kinds of government organizations. The direct form of collaboration between local governments is the creation of a forum for program objectives. The forum is called the Adolescent Counseling Information Center (ACIC) for adolescents and Adolescent Families Development (AFD) for families who have adolescent aged 10-24 years. ACIC is implemented in schools, and AFD is implemented in neighborhood units. The local government organization that collaborates is the Family Planning Department, the Education Department, the Health Department, the Sub-district and the Urban Village. In the collaboration process, the strengthening theme is mutual interdependence and joint interaction. The reinforcing factor for mutual interdependence is the similarity of tasks and functions, availability of resources, and 
the strength of the problem solved. The reinforcing factor for join interaction is the commitment of the parties involved and the trust of the target object. The collaborative working relationship consists of coordination, consolidation, consultation, and command. These relationships depend on sectoral and regional classifications.

\section{ACKNOWLEDGEMENT}

This paper is based on a joint research project No. 0045/E3/LL/2018 that funded by the Ministry of Research, Technology and Higher Education, Indonesia. The term of research funding is cooperative research for college 2018 or 'PEKERTI' 2018. A research collaboration involved Universitas Gadjah Mada (UGM) and Universitas Muhammadiyah Makassar (Unismuh). The research team consisted of Agus Heruanto Hadna from Universitas Gadjah Mada (UGM) as a research supervisor and Nasrulhaq Nasrulhaq from Muhammadiyah University of Makassar (Unismuh) as a field researcher.

\section{REFERENCES}

Adeleye, O. A., \& Ofili, A. N. (2010). Strengthening intersectoral collaboration for primary health care in developing countries: Can the health sector play broader roles? Journal of Environmental and Public Health, 2010. https:// doi.org/10.1155/2010/272896

Axelsson, R., \& Axelsson, S. B. (2006). Integration and collaboration in public health - A conceptual framework. International Journal of Health Planning and Management, 21(1), 75-88. Retrieved from http://ovidsp.ovid.com/ ovidweb.cgi?

$\mathrm{T}=\mathrm{JS} \& \mathrm{PAGE}=$ reference $\& \mathrm{D}=$ emed 7 $\& N E W S=N \& A N=2006159104$
Baarle, S. Van. (2019). Beyond Command and Control: Tensions Arising From Empowerment Initiatives. https:// doi.org/10.1177/017084061881 8600

Bao, J., Bhalla, K., \& Bennett, S. (2015). Evidence to inform intersectoral policies: A comparison of health and transport sector evidence in support of road traffic injury prevention. Health Research Policy and Systems, 13(1), 1-10. https:// doi.org/10.1186/s12961-0150008-9

Burgess, T., Braunack-Mayer, A., Tooher, R., Collins, J., O’Keefe, M., Skinner, R., ... Marshall, H. (2016). Optimizing intersectoral collaboration between health and education: The Health Bridges study. Journal of Public Health (United Kingdom), 38(4), e430-e437. https:// doi.org/10.1093/pubmed/fdv190

Chalmers, A. W. (2014). In over their heads: Public consultation, administrative capacity and legislative duration in the European Union. https:// doi.org/10.1177/146511651452 9849

Creswell, J. W. (2014). Research Design Qualitative, Quantitative, and Mixed Method Approaches-SAGE Publications (2013).pdf (4th ed.). California: Sage Publication.

Freudenberg, N. (2008). Intersectoral Approaches to Health Promotion in Cities. In L. Potvin \& D. McQueen (Eds.), Health Promotion Evaluation Practices in the Americas (pp. 191-219).

Hellevik, S. B. (2012). The pattern and challenges to multisectoral HIV / AIDS coordination in Tanzania. https:// 
Available Online at https://journal.unismuh.ac.id/index.php/otoritas

Otoritas : Jurnal Ilmu Pemerintahan, 9 (1), April 2019, 26

doi.org/10.1177/002085231244

7060 .

Hendriks, A. M., Jansen, M. W. J., Gubbels, J. S., De Vries, N. K., Molleman, G., \& Kremers, S. P. J. (2015). Local government officials[U+05F3] views on intersectoral collaboration within their organization - A qualitative exploration. Health Policy and Technology. https:// doi.org/10.1016/ j.hlpt.2014.10.013

Hendriks, F. (2014). Understanding Good Urban Governance: Essentials, Shifts, and Values. Urban Affairs Review, 50(4), 553-576. https:// doi.org/10.1177/107808741351 1782

Jimenez, B. S., \& Hendrick, R. (2010). Is Government Consolidation the Answer?, 42(3), 258-270. https://

doi.org/10.1177/0160323X1038 6805

Kang, E. (2016). Intersectoral collaboration for physical activity in Korean Healthy Cities. Health Promotion International, 31(3), 551561. https://doi.org/10.1093/ heapro/dav020

Larsen, M., Koudenburg, O. A., Gulis, G., \& Rantala, R. (2014). Intersectoral action for health: The experience of a Danish municipality. Scandinavian Journal of Public Health, 42 (7), 649-657. https:// doi.org/10.1177/140349481454 4397

Liu, X., \& Zheng, L. (2014). Crossdepartmental collaboration in one -stop service center for smart governance in China: Factors, strategies and effectiveness. Government Information Quarterly, 1-7. https://doi.org/10.1016/ j.giq.2015.12.001
McQueen, D. V. (2013). Global handbook on noncommunicable diseases and health promotion. Global Handbook on Noncommunicable Diseases and Health Promotion, 1481. https:// doi.org/10.1007/978-1-46147594-1

Mitchell, P. F., \& Pattison, P. E. (2012). Organizational culture, intersectoral collaboration and mental health care Penelope Fay Mitchell Philippa Eleanor Pattison Article. Journal of Health Organization and Management, 26(1), 32-59.

Osborne, S. P. (2010). The New Public Governance?: Emerging Perspectives on the Theory and Practice of Public Governance. New York: Routledge. https:// doi.org/10.4324/978020386168 4

Palinkas, L. A., Fuentes, D., Finno, M., Garcia, A. R., Holloway, I. W., \& Chamberlain, P. (2014). Interorganizational collaboration in the implementation of evidencebased practices among public agencies serving abused and neglected youth. Administration and Policy in Mental Health and Mental Health Services Research, 41(1), 74-85. https://doi.org/10.1007/ s10488-012-0437-5

Pucher, K. K., Candel, M. J. J. M., Krumeich, A., Boot, N. M. W. M., \& De Vries, N. K. (2015). Effectiveness of a systematic approach to promote intersectoral collaboration in comprehensive school health promotion-a multiple-case study using quantitative and qualitative data. BMC Public Health, 15(1). https:// doi.org/10.1186/s12889-0151911-2

Savage, G. T., Bunn, M. D., Gray, B., Xiao, Q., \& Wang, S. (2010). Stakeholder 
Available Online at https://journal.unismuh.ac.id/index.php/otoritas

Otoritas : Jurnal Ilmu Pemerintahan, 9 (1), April 2019, 27

ollaboration: implications for Stakeholder Theory and Practice. Journal of Business Ethics, 96(1), 21-26. Retrieved from http:// link.springer.com/ article/10.1007/s10551-0110939-1\%255Cnhttp://

link.springer.com/ article/10.1007/s10551-0110939-1/fulltext.html

Smith, C. R. (2009). Institutional determinants of collaboration: An empirical study of county open-space protection. Journal of Public Administration Research and Theory, 19(1), 1-21. https:// doi.org/10.1093/jopart/mum037

Spiegel, J., Alegret, M., Clair, V., Pagliccia, N., Martinez, B., Bonet, M., \& Yassi, A. (2012). Intersectoral action for health at a municipal level in $\mathrm{Cu}$ ba. International Journal of Public Health, 57(1), 15-23. https:// doi.org/10.1007/s00038-0110279-z

Tooher, R., Collins, J., Braunack-Mayer, A., Burgess, T., Skinner, S. R., O'Keefe, M., ... Marshall, H. S. (2017). Intersectoral collaboration to implement schoolbased health programmes: Australian perspectives. Health Promotion International, 32(2), 312-321. https:// doi.org/10.1093/heapro/dav120

Wilson, J. M., \& Grammich, C. A. (2017). Consolidation of Police and Fire Services in the United States, 27 (3), 203-221. https:// doi.org/10.1177/105756771769 8012. 